\title{
建設資材価格等における移動平均乘離率 を用いた価格予測手法に関する一考察
}

\author{
村田 $\quad$ 裕介 1 ・有森 $\quad$ 正浩 2 ・鈴木 信行 ${ }^{3}$ \\ 1正会員 一般財団法人 建設物価調査会（广103-0011 東京都中央区日本橋大伝馬町11番8号） \\ E-mail: y-murata@kensetu-bukka.or.jp \\ 2アイサワ工業株式会社（テ700-0822 岡山県岡山市北区表町1丁目5番1号） \\ E-mail:arimori@aisawa.co.jp \\ 3正会員＼cjkstart東洋大学理工学部都市環境デザイン学科（テ350-8585 埼玉県川越市鯨井2100） \\ E-mail:suzuki060@toyo.jp
}

\begin{abstract}
公共工事の入札時における予定価格の設定や工事の実行予算の策定，工事実施中におけるコス卜管理な ぞに用いられる建設資材価格等について，毎月実施する定期調查間のタイムラグによる影響の抑制や，応 札者における取引先等との実勢価格の妥当性を評価するために，定量的な分析を行い物価変動によるリス クに対応した客観的かつ精度の高い資材価格等の予測モデルの構築を行った。

分析は予測価格を目的変数とし, 今月の価格, 前月から今月の価格変動率, 実績価格との乘離率から求 めた次月の市況気配を説明変数と寸る重回帰分析を行った. 分析結果の評価方法は, 予測值の実績值に対 する相対誤差により評価した。 その結果，過去の価格情報を使用して算出された価格と比較することで検 証を行ったところ，精度の高い予測モデル構築手法を考案することができた.
\end{abstract}

Key Words : estimation , time lag, market, deviation rate , material prices forecasting

\section{1. はじめに}

建設資材や市場単価の価格情報は，公共工事の入札時 における予定価格や工事の実行予算の策定，工事実施中 におけるコスト管理などに用いられる重要なデータであ る. 昨今, 公共工事の不調・不落が話題となっている. それらは 2006 年頃より目立つようになってきたとされ る1).

公共工事の入札時において設定される予定価格は，主 として標準歩掛と単価を用いて行われる，労務費や資材 価格は，定期的に実勢価格の調査が行われその都度改訂 されている. しかしながら，入札手続きの開始（入札公 告）から実際に入札が行われるまでには入札方法にもよ るが数か月の期間を要する，その間に資材価格に大きな 変動があれば，予定価格と実勢価格には乘離が生じるこ ととなる．これらは，予定価格の設定から入札までに数 カ月の期間を要する場合，入札直前に最も新しい資材価 格で予定価格を再計算しなかった場合に起こる問題であ る.しかし，定期的な資材調查などによる最新価格を用 いた場合でも，短期の価格変動がある場合には，予定価 格と実勢価格の乘離は避けられない.

公共工事の当初入札時において，積算基淮による歩掛
や単価などがすべて工事の現場条件を反映することは難 しい. 工事契約後の物価変動への対応として，「公共工 事標準契約約款」第 25 条（スライド条項）があるが当 初入札よりも後での対応となる，そのため応札者は，契 約後の不確定要素が多く円滑な施工が難しいのではとい ったリスクを想定して，入札への不参加や契約後のリス クに対する費用を加味した応札価格をとることがあると される.このような応札者のとる行動が，不調・不落の 発生原因の一つとなっているとされる ${ }^{12)}$.

国土交通省では，2014 年度より適正利潤の確保を可 能とするための予定価格の適正な積算をする設定に向け た取り組みを行っている ${ }^{3)}$ ．予定価格が実際の取引価格 と乘離しているおそれがある場合には，応札者から提出 された見積書を参考として予定価格を算定する方式を新 たに採用しており，労務単価，資材等の実勢価格を適切 に反映する事の必要性が示されている.

可能な限り最新の労務単価，資材等の情報を捉えるこ とは重要であるが，応札者が取引先等の情報からタイム ラグを考慮した実勢価格による見積書を提出し，発注者 側に定期調查などの価格データしかない場合には，見積 書の妥当性を評価することは難しい.

価格変動による予定価格と実勢価格の乘離や適正に見 
積書を評価できない要因には，発注側と応札側がもつ価 格情報にタイムラグが生じることで, 情報の非対称性 ${ }^{4}$ が存在する状況となっている事が挙げられる.

資材価格等は，建設市場内だけでなく国際情勢など 様々な要素で変動する.このため工事契約後の数力月先 までの価格予測は容易ではないが，定期的な調査による 次期調查までの間における価格の值を内挿するような予 測が出来ればタイムラグの解消に有効であると考える.

本研究では, 短期の価格変動による予定価格と実際の 取引価格と乘離するおそれがある場合や応札者から提出 された見積書の妥当性を評価する場合に生じるタイムラ グ解消を目的とした建設資材等の価格変動予測手法につ いて検討した.

\section{2. 資材価格の変動誤差}

図-1は，主要資材の中でも価格の変動が著しい異形棒 鋼（SD295A D16 東京地区大口）を対象として，予定価 格の設定に用いられた資材単価が1カ月前のものであっ た場合を例として，価格で生じる誤差を2010年4月から 2015年3月（5年間）まで示したものである. マーカーの 「○は「建設物価」5)に掲載された1カ月おきの定期 調査で求められた資材価格の実績值である.

は1 ケ月前の価格を用いて予定価格が設定された時の積算上 の資材価格を示しており，(1) 式に示寸平均相対誤差 (RAE ; Relative Average Enor) 及び最大相対誤差 (RME ; Relative Maximum Error) を確認した.

$$
R A E=\frac{1}{n} \sum_{t=1}^{n}\left|P_{c, t}-P_{o, t}\right| / P_{o, t}
$$

ここで， $R A E$ は平均相対誤差 (\%) , $n$ はデー夕数, $P_{c, t}$ は予測值, $P_{o, t}$ は実績值である.

マーカーの「の」は，実績值に比べて大きな誤差が生 じている. 図示した期間中の平均相対誤差は 1 カ月前で

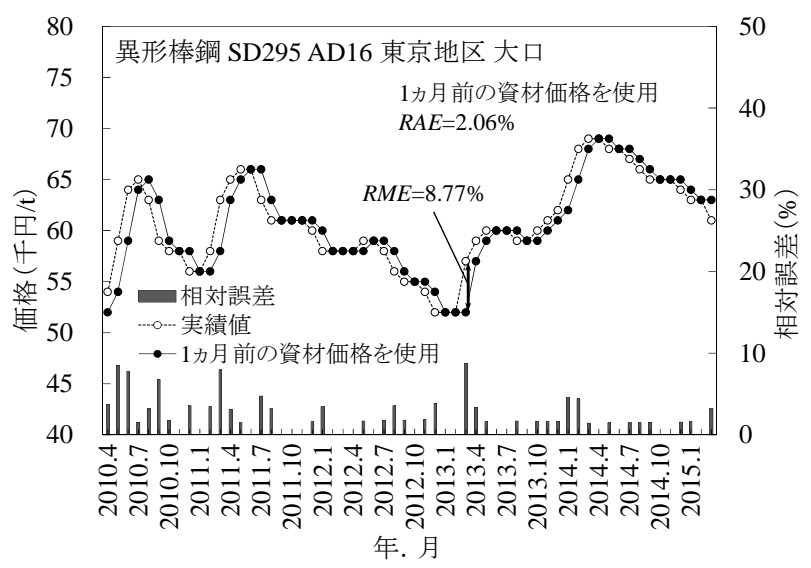

図-1 1 月月前の資材価格を使用した場合の誤差
2.06\%であり，過去には資材価格の変動が最も大きくな った時期は 2013年 3 月で相対誤差は 8.77\%となっている. 定期調査は，工事発注官庁や建設物価調査会などの調 查機関において行われているが，調查の間隔は一般的に 1 カ月である. 定期調查の報告直後であればタイムラグ による実勢価格との乘離はほとんじ生じないが，価格急 変動期には，次の定期調查報告までのおおむね 1 力月の 時間経過でもタイムラグによる乘離を生じることになる.

資材等の取引実績をタイムリーに把握できるような調 査体制が構築でき，定期調査の時間間隔を短くする事が 可能であれば，価格の靟離を小さくすることができるが， 現在の1カ月より短い間隔で精度が確保された定期調査 を行うことは，今の調査体制のままでは困難である.

\section{3. 市況気配を用いた予測モデル}

\section{(1) モデル変数の設定}

建設工事費の積算に用いられる建設資材等の物価変動 や価格決定要因を取り上げた論文は少ない，既往研究に は, 宮本らのの事例がある。この研究では, 異形棒鋼な ど主要7資材の価格を被説明変数とし, 原油価格, 鉄ス クラップ価格など価決定要因と考えられる10項目を説明 変数として, 重回帰分析により, 価格形成モデルを作成 している，そして，そのモデルと，ARIMAモデルで予 測した各説明変数の值を用いて2006〜2008年の3年間で3 カ月毎の価格予測が試みられている。この手法では, 価 格が急激に変動する資材での予測精度が良くないことや， 被説明変数である価格の予測が説明変数の予測に依存し ているためモデルの有意性に限界があることなど，いく つかの課題が残るとされている.

これらのことを踏まえ, 本研究では, 少ない説明変数 で, 特に予測が必要となる説明変数は極力減らすことと し, 過去から現在までの資材価格の時系列データから得 られる価格変動の情報と, 現在から先に向けた情報とし ての市況気配に着目して価格の予測モデルを構築するこ ととした.

図-2は，市況気配を用いた予測モデルの概念を示し

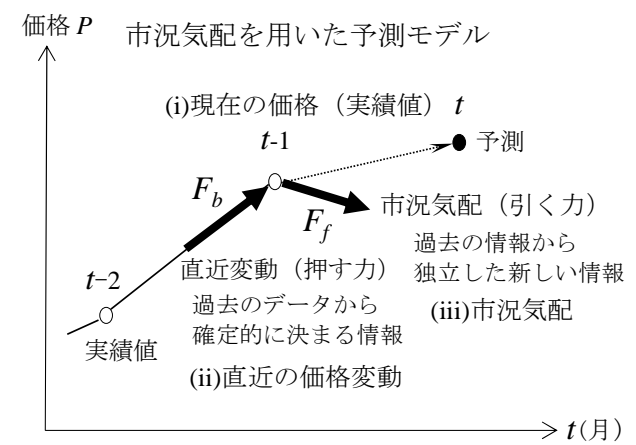

図-2 市況気配を用いた予測モデルの概念 
たものである，現在の情報〔(i)現在の価格〕と過去のデ 一夕から確定的に決まる情報〔(ii)直近の価格変動（押 寸力 $\left.F_{b}\right)$ ], 過去の情報から独立した新しい情報〔(iii) 市況気配（引く力 $F_{f} ）$ ] の 3つをとにした説明変数を 用いて重回帰分析を行い予測モデルの作成を行っている. ここでいう市況気配とは，価格が現在から先に向けて変 動する時に上向く・下向くかを示寸情報である.

市況気配を用いた予測モデルの算定式は，次の（2） 式である，計算の刻みは1カ月である.

$$
y=a+b_{1} \times x_{1}+b_{2} \times x_{2}+c_{1} \times D_{1}+c_{2} \times D_{2}
$$

ここで， $y$ は時刻 $t$ の予測価格 (円/t),$a$ は定数， $b_{1}$, $b_{2} ， c_{1}, c_{2}$ は偏回帰係数， $x_{1}$ は今月 $t-1$ の価格 (円/t),$x_{2}$ は前月 $t-2$ から今月 $t-1$ の価格変動率 (今月価格前月価 格，\%) である. $D_{1}, D_{2}$ は $t-1$ から $t$ に向けた市況気配に 関するダミ一変数で, 弱含み（下向き）の時 $D_{1}=1$, $D_{2}=0$, 強含み（上向き）の時 $D_{1}=0, D_{2}=1$, 横ばいの時 $D_{1}=0, D_{2}=0$ である.

\section{（2）移動平均乘離率を用いた市況気配の設定}

分析の対象とする資材は，異形棒鋼（SD295A D16 東 京地区 大口）を対象とした．モデルパラメータの決定 期間（モデルの同定期間）は，価格変動の向きが上下に 切替わる回数が多かった期間とし，2010年4月から2015 年3月（5年間），モデル同定期間以外におけるモデルの 有用性を検証する期間は，2005年4月から2010年3月（5 年間) とした.

資材価格の時系列データからは，(a)今月 $t-1$ 価格（実 績值） と過去からの価格の動きである (b)前月 $t-2$ からの 価格変動率（今月/前月）を捉える事ができる。一方， 調査後にどのように価格が動くかという将来に向けた情 報（引く力）については，(c)次月 $t$ の市況気配を捉えて 変数に適用することとした.

将来の情報である市況気配を捉えるには，建設価格の 情報誌呅から引用する事ができる，その他に，経済誌， 業界誌などの情報から総合的に検討寸る手法も考えられ るが，膨大な情報を収集したうえでの市況判断はタイム リ一性が久如寸る. そこで，本研究では資材価格の時系 列データから得られる情報のみを用いて市況気配を把握 し，変数に適用する手法を検討した.

株式の売買においてトレンド転換の判断（変極点）を 見出す手法の一つにグランビルの法則がある.この法則 は，移動平均を用いて価格を平滑化することで不規則変 動がならされ，データ全体の変化の傾向を捉えることが 出来るというものである. グランビルの法則は, 株価の 予測手法として広く利用されており，この法則を基とし た株価予測手法の研究も行われている》。

図-3は，異形棒鋼（SD295AD16東京地区大口）の価

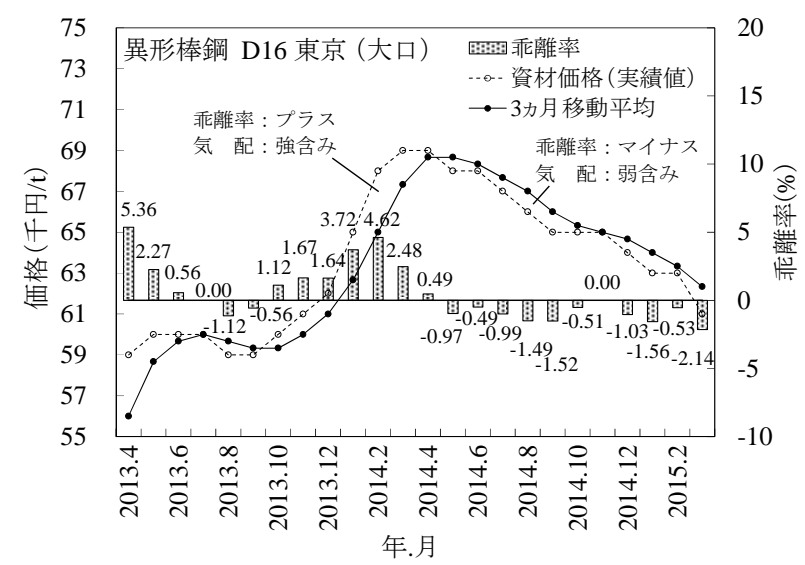

図-3 3 カ月移動平均による乘離率と市況気配の関係

(1)移動平均乘離率が小さい場合

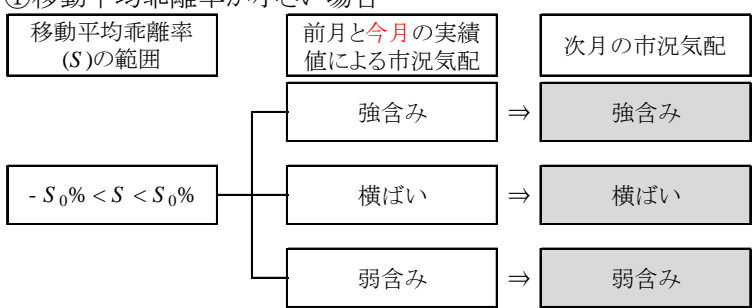

(2)移動平均乘離率が大きい場合

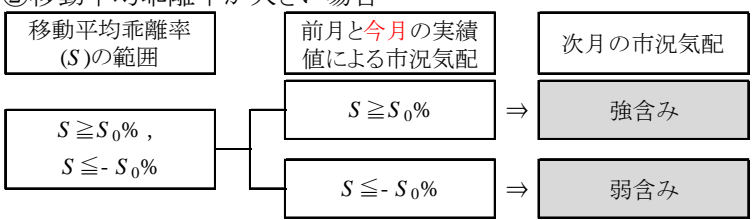

図-4 移動平均乘離率を用いた市況気配の設定方法

格変動と3カ月移動平均による乘離率を例に乘離率と市 況気配の関係について，2010年4月から2015年3月を抜粋 して示したものである. 移動平均乘離率 $S$ の算定式は(3) 式のとおりとなる.

$$
S=(T-X) / X \times 100
$$

ここで，S は移動平均乘離率 (\%)， $T$ は異形棒鋼 （SD295A D16 東京 大口）の実績価格（千円/t），Xは $N$ 力月移動平均值 $(千 円 / \mathrm{t}) \quad(N$ : 算出の対象とする期 間（月））である.

乘離率と市況気配の関係を観察すると, 乘離率（絶対 值）がある程度大きくなると，乘離率がプラス（上向 き）になる時は「強含み」の市況気配，乘離率がマイナ ス（下向き）になる時は「弱含み」の市況気配となる傾 向が確認できる.このことより, 靟離率のプラス・マイ ナスと乘離率の大きさから，市況気配を設定することを 考えた.

市況気配の設定には，乘離率がその值を超えたら価格 変化の向きが変わるという閾值 $\left( \pm S_{0}\right)$ を想定した，そ

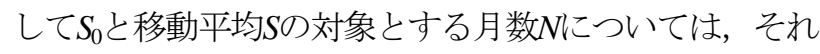
ぞれの值を変えながら試算を行い，推定された市況気配 と実績の市況気配の適合度が，最も大きくなるケースに おける $S_{0}, N の$ 值を最適值とすることとした. 


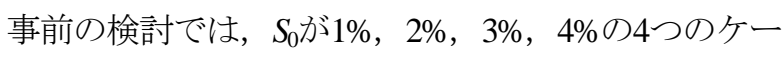
スで，各ケースについて，Nが2力月，3カ月，4カ月の ときの試算を行った．その結果， $S_{0}$ が $\%, N$ $\%$ 月月の 時に市況気配の適合度が最も大きく, それらの值を最適 值とした. 図-4に市況気配の設定方法について整理した 結果を示す.

\section{4. 資材価格の予測モデル}

\section{(1) 資材価格の予測モデルの作成}

資材価格の予測モデルは，予測価格を被説明変数とし て，今月の資材価格，前月から今月の価格変動率，次月 に向けた市況気配を説明変数として，重回帰分析を行っ た. 分析に用いるデータは，建設工事の主要資材の中で も価格の変動が著しい異形棒鋼（SD295A D16 東京地区 大口）を対象とし，検証の比較対象には1力月前の資材 価格を使用した場合の平均相対誤差を指標とし，これよ りも精度の高い予測モデルの構築を試みた。

説明変数として設定している(a)今月の資材価格，(b)前 月から今月の価格変動率の算出に用いる資材価格のデー タは，建設物価調査会から発刊されている「建設物価」 5)の掲載值を用いた。 また，(c)次月の市況気配の変数は， 前述した図-4による移動平均乘離率を用いた市況気配の 設定方法により決定した．パラメータの決定期間は， 2010年4月から2015年3月の5年間を対象とした。

資材価格の予測モデルの算定式は(4)式のとおりであ る.

$$
\begin{aligned}
y= & 8.810+0.850 \times x_{1}+0.275 \times x_{2} \\
& +0.114 \times D_{1}+1.027 \times D_{2}
\end{aligned}
$$

ここで， $y$ : 予測価格 (千円/t）， $x_{1}$ : 今月の価格（千 円/ t ）， $x_{2}$ : 前月から今月の価格変動率（今月/前月）, $D_{1}$ : 弱含み（次月への市況気配）， $D_{2}$ : 強含み（次月 の市況気配) である.

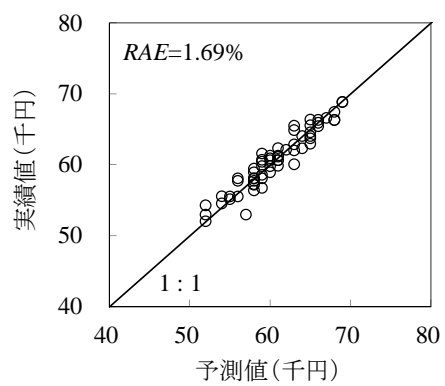

図-5 資材価格の実績值と予測值の関係

表-1 偏回帰係数と標準化偏回帰係数（資材価格）

\begin{tabular}{lrrr}
\hline & 偏回帰係数 & \multicolumn{2}{c}{ 標隻化 } \\
偏回帰係数 & \multicolumn{1}{c}{$t$ 值 } \\
\hline$x_{1}$ (今月の価格) & 0.850 & 0.877 & 21.290 \\
$x_{2}$ (前月から今月の価格変動率 $)$ & 0.275 & 0.193 & 2.555 \\
$D_{1}$ (弱含み-次月の市況気配) & 0.114 & 0.012 & 0.223 \\
$D_{2}$ (強含み-次月の市況気配 $)$ & 1.027 & 0.110 & 1.740 \\
\hline
\end{tabular}

なお重回帰式で問題となる多重共線性の有無の判断基 準には分散拡大要因（Variance Inflation Factor，以下VIF） を用いた. (4)式の各説明変数におけるVIF值は $D_{2}$ で最大 值を示し，2.39であった．一般的に多重共線性が有る場 合のVIF值は10以上とされていることより多重共線性が 無いものと判断した.

各説明変数が予測価格に与える影響の強さについては, データを標準化した重回帰分析から求められた標準化偏 回帰係数により評価した. 表-1には標準化偏回帰係数を 示しているが，標準化偏回帰係数は今月の価格 0.877, 前月から今月の価格変動率 0.193 , 弱含夕（次月の市況 気配） 0.012 , 強含み（次月の市況気配） 0.110 であり， 各説明変数が予測価格に与える影響の強さは，今月の価 格が最も大きくなっていることが示された.

図-5は予測值と実績值の関係を散布図で示したもので あるが，マーカーはおおむ称角線（1：1の直線）の近 くに集まっており，予測值は実績值によく合っている.

\section{（2）資材価格予測モデルの推定精度の検証}

図-6は2010年4月から2015年3月（5年間）の期間で，資 材価格の予測モデル(4)式による予測結果と同期間にお ける資材価格 (実績值) を使用した場合との価格誤差を 示したものである. 分析期間中の資材価格の予測モデル による予測值と実績值との平均相対誤差1.69\%が得られ た．精度の検証は，前述の図-1で示した1カ月前の資材 価格を使用した場合の実績価格との間で生じる誝差と比 較して行った. 分析期間における資材価格の予測モデル を使用した場合の予測值と実績值との平均相対誤差 1.69\%（最大相対誤差7.03\%）であり，1力月前の資材価 格を使用した場合における平均相対誤差2.06\%（最大相 対誤差 8.77\%）より高い精度の予測モデルが得られた.

一般的に重回帰分析では，決定係数でモデルの精度が 評価されるが，決定係数の大きさは予測值と実績值の相 関の強さを表しても，必ずしも両者の值がよく合ってい ることを示すものではない，このため今回の分析では， モデルの精度は平均相対䛊差で評価している，モデルの

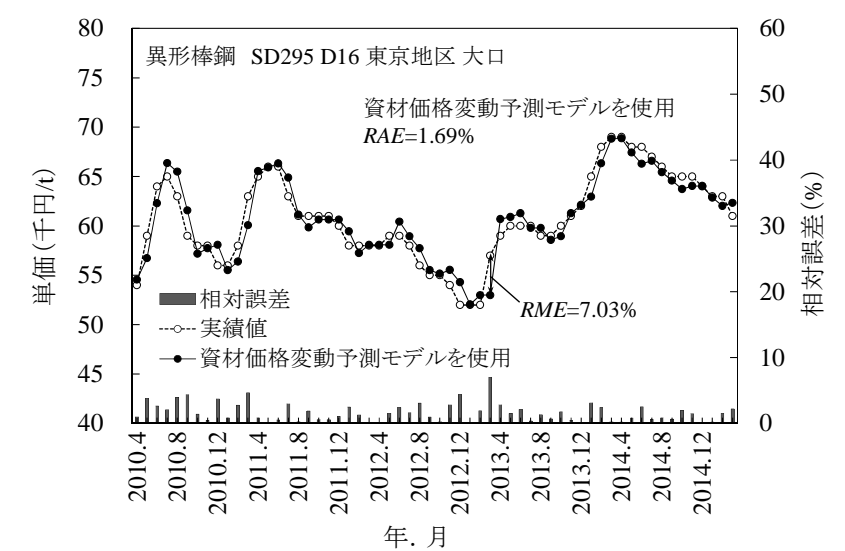

図-6＼cjkstart実績值と資材価格の予測モデル式による価格 (モデル同定期間) 


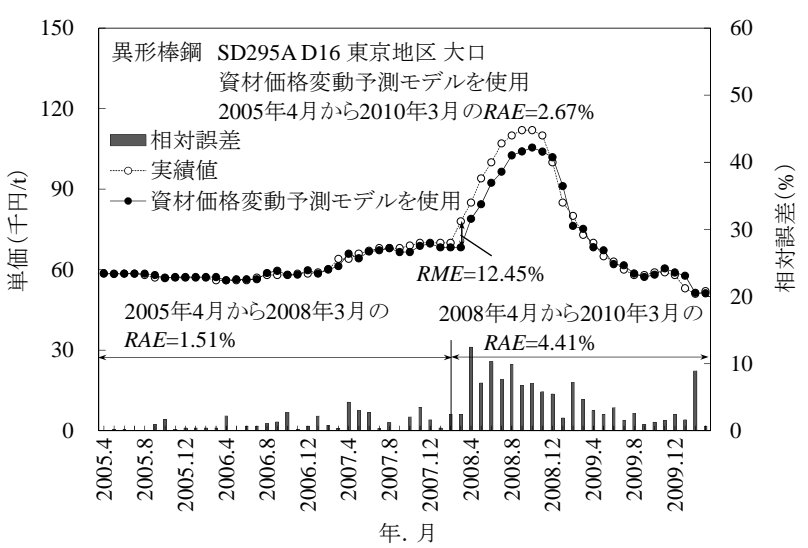

図-7＼cjkstart実績值と資材価格の予測モデルによる価格の比較 (モデル検証期間)

信頼性の確認は，同定されたモデルを用いて同定期間と は別の期間でも同じような精度が得られるか確認するこ とにより行った. なお参考として, 決定係数は0.91であ った， t值は表-1に示すとおりであり，特に $D_{1}$ で小さな 值となっている. ダミ一変数である $D_{1}, D_{2}$ を除いて重回

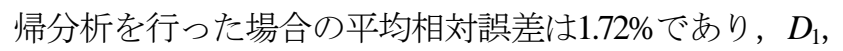
$D_{2}$ 用いた方がよい予測精度が得られている。

\section{（3）同定期間以外におけるモデルの有用性の検証}

図-7は，重回帰分析により得られた資材価格の予測モ デル(4)式に2005年4月から2010年3月（5年間）の期間に おける資材価格の実績值を入れて予測值を算出し，実績 值との比較によりモデル検証を試みたものである.

予測值と実績值の検証期間における平均相対誤差は 2.67\%であった。平均相対誤差が大きくなっている期間 は2008年4月から2010年3月の資材価格の高騰（下落）が 大きかった時期であり平均相対誤差は4.41\%である。こ れ以前の2004年4月から2008年3月の期間においては，平 均相対誤差は1.51\%であり，この期間で，資材価格の予 測モデルの同定期間の平均相対誤差 1.69\%と比較しても, 推定精度は良好である.

平均相対誤差が大きくなった2008年4月から2010年3月 は, 新興国需要の増加やリーマンショックの影響から資 材価格の高騰（下落）が特に大きかった期間である.こ のような期間では, モデル式の当てはまりが良くない状 況がみられる。

\section{5. 市場単価の予測モデル}

\section{（1）市場単価への適用性}

前述の資材価格の予測の分析で用いた手法を，市場単 価に適用して検討した結果について記す，対象とした市 場単価の工種は，鉄筋工の鉄筋加工・組立（土木一般構 造物 東京地区）である。この市場単価の構成内容は,

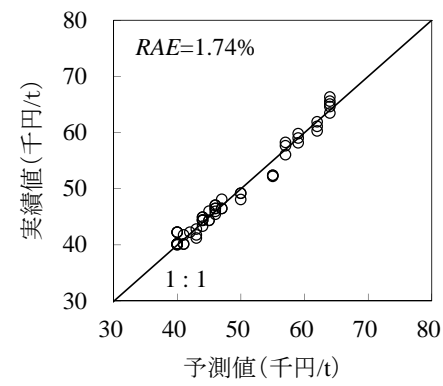

図-8 市場単価の実績值と予測值の関係

表-2 偏回帰係数と標準化偏回帰係数（市場単価）

\begin{tabular}{lrrr}
\hline & 偏回帰係数 & \multicolumn{2}{c}{ 標準化 } \\
偏回帰係数 & \multicolumn{1}{c}{$t$ 值 } \\
\hline$x_{1}$ (今月の価格) & 1.059 & 0.957 & 46.874 \\
$x_{2}$ (前月から今月の価格変動率) & 0.241 & 0.057 & 2.525 \\
$D_{1}$ (弱含み-次月の市況気配) & 1.071 & 0.017 & 0.820 \\
$D_{2}$ (強含み_次月の市況気配) & 1.622 & 0.084 & 4.228 \\
\hline
\end{tabular}

機械と労務である. 市場単価のデータは, 建設物価調査 会から年4回（4月，7月，10月，1月）発刊されている 「土木コスト情報」 ${ }^{8)}$ の掲載值を用いた。市場単価の発 表は3カ月単位であることから, 重回帰分析を行うため の必要デー夕数を補うために, 3力月で1データである市 場単価を3カ月間（2データ分）を内挿して適用した．市 場単価の予測モデルの同定期間は，資材価格の分析と同 様に2010年4月から2015年3月（5年間）で，検証期間は 2005年4月から2010年3月（5年間）とした.

市場単価の予測モデルの算定式は(5)式のとおりであ る.

$$
\begin{aligned}
y= & -2.220+1.059 \times x_{1}+0.241 \times x_{2} \\
& +1.071 \times D_{1}+1.622 \times D_{2}
\end{aligned}
$$

ここで, $y$ : 予測価格 $(千 円 / \mathrm{t}), x_{1}$ : 今月の価格（千 円 $/ \mathrm{t}$ ）， $x_{2}$ : 前月から今月の価格変動率 (今月/前月), $D_{1}$ : 弱含み（次月への市況気配）, $D_{2}$ : 強含み（次月へ の市況気配）である. なお (5)式の各説明変数における VIF值は $D_{2}$ で最大值を示し，1.18であったことより多重 共線性が無いものと判断した。

表-2には標準化偏回帰係数を示しているが, 標準化偏 回帰係数は今月の価格 0.957 , 前月から今月の価格変動 率 0.057 , 弱含夕（次月の市況気配） 0.017 , 強含み（次 月の市況気配） 0.084 であり, 各説明変数が予測価格に 与える影響の強さは，今月の価格が大きいことが示され た．図-8に示寸散布図のとおり，マーカーはおおむ対対 角線（1: 1の直線）の近くに集まっており，予測值は実 績值によく合っている.

\section{（2）市場単価の予測モデルの推定精度の検証}

図-9は分析期間における市場単価の予測モデルを使用 した場合の予測值と実績值を示したものである．平均相 対誤差は $1.74 \%$ (最大相対誤差5.63\%)であった. 3力月前 の市場単価を使用した場合による平均相対誤差 $2.54 \%$

（図-10）と比較して高い精度であることが確認できた. 


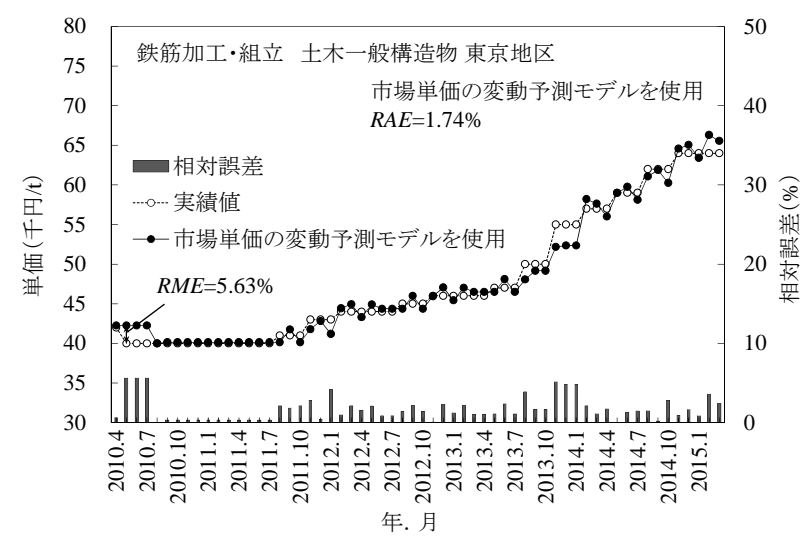

図-9＼cjkstart実績值と市場単価の予測モデル式による価格 (モデル同定期間)

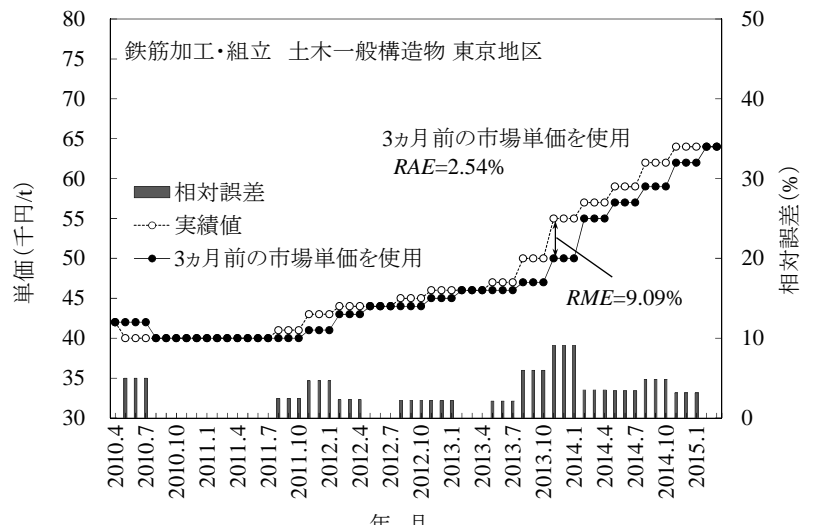

図-10 実績值と 3 力月前の市場単価使用した場合の価格

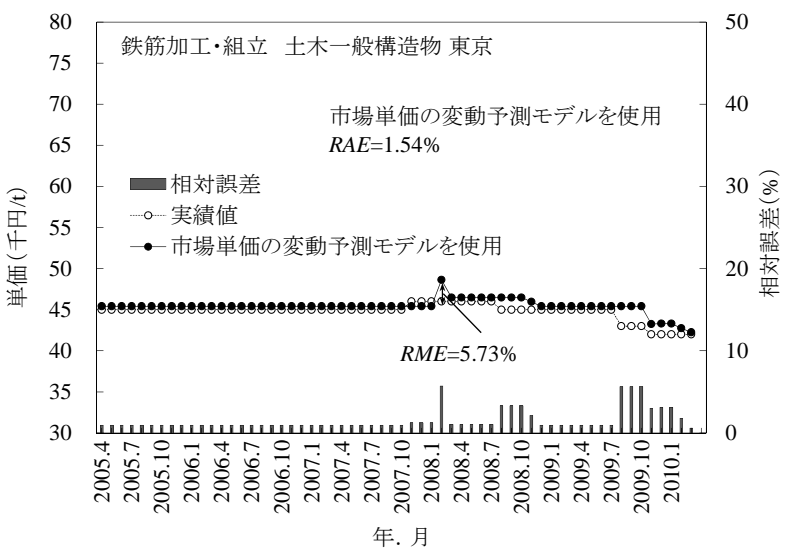

図-11 実績值と市場単価の予測モデルによる価格の比較 (モデル検証期間)

参考として，決定係数は0.98，t值は表-2に示したとお りである.

\section{（3）同定期間以外におけるモデルの有用性の検証}

図-11は，重回帰分析により得られた市場単価の予測 モデル(5)式に2005年4月から2010年3月（5年間）の期間 における市場単価の実績值を入れて予測值を算出し，実 績值との検証を試みたものである.

予測值と実績值の検証期間における平均相対誤差は 1.54\%であった。これは同定期間の平均相対誤差 $1.74 \%$ と 比較した場合よりも高い推定精度が得られることが示さ れた。

\section{6. 工事費による予測が工事価格の適正化に与える 効果についての検証}

\section{（1）工事費による検証の概要}

これまでの分析では，資材価格の予測モデルと市場単 価の予測モデル（以下，市況気配を用いた予測モデルと いう）の構築を行った。ここではこれらのモデルを使用 して算出した予測值（資材価格と市場単価）により鉄筋 工事費の算出を行い，実績値による工事費との比較検証 を行った.

検証の比較対象には，1カ月前の資材価格および3カ月 前の市場単価を使用した場合の鉄筋工事費を用いて，実 績値により算出した鉄筋工事費と差額および平均相対誤 差で評価を行った.

\section{（2） 実績值との価格差}

表-3は，2014年1月時点で2014年2月の鉄筋工事費の予 測值を算出することを例にして，1力月前の資材価格・3 カ月前の市場単価を使用した場合の工事費および市場気 配を用いた予測モデルを使用した場合の鉄筋工事費 （2014年2月の予測値）を算出し，2014年2月の実績値と の価格差を比較したものである．表-3の(ア)は，2014年2 月の実績值を用いて算出した鉄筋工事費 127,100 円/tであ る. (们は1力月前の資材価格・3力月前の市場単価を使用 した場合での鉄筋工事費は122,000円/t となり，(乃実績值 との価格差はマイナス5,100円/tである。一方，(宁)は市場 気配を用いた予測モデルにより算出した場合の鉄筋工事 費 126,000円/tであり，(乃)実績值との価格差は マイナス 1,100円である。市場気配を用いた予測モデルにより試

表-3 実績值，1カ月前の資材価格および市況気配を用いた 予測モデルによる鉄筋工事費の比較

鉄筋工 $1 t$ 当たり単価表 東京地区

\begin{tabular}{|c|c|c|c|c|}
\hline 名称 & 規格 & 単位 & 数量 & 摘要 \\
\hline 鉄筋費 & $\begin{array}{l}\text { 異形棒鋼SD295A } \\
\text { D16 }\end{array}$ & $t$ & 1.03 & $\begin{array}{l}1.000 \mathrm{t} \times 1.03 \\
(\text { ロス補正) }\end{array}$ \\
\hline 施工費 & $\begin{array}{l}\text { 加工組立(クレーン } \\
\text { 賃料含む) }\end{array}$ & & 1 & 市場単価,10t以上※ \\
\hline 諸雑費 & & 式 & 1 & 端数処理 \\
\hline
\end{tabular}

鉄筋工 $1 \mathrm{t}$ 当たり工事費の比較表(円/t)

(イ)1力月前の資材 (宁市場気配を用 価格・3力月前の市 いた予測モデル

(ア)実績值による 場単価を使用した を使用した場合

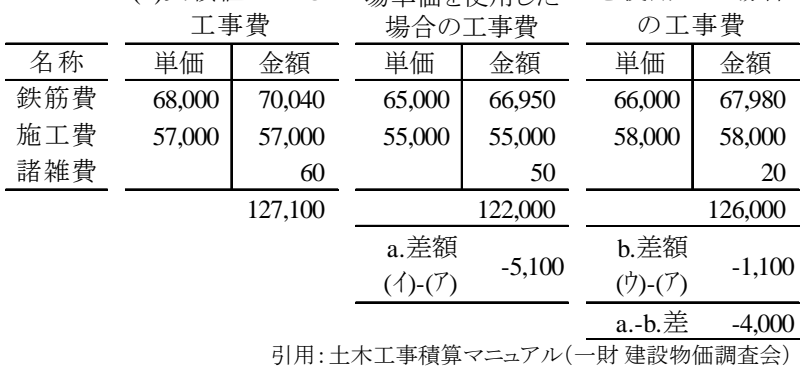




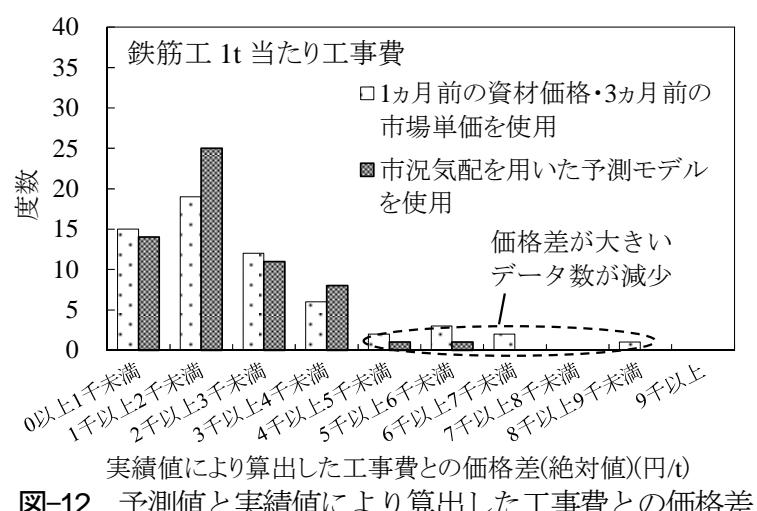

図-12 予測值と実績值により算出した工事費との価格差

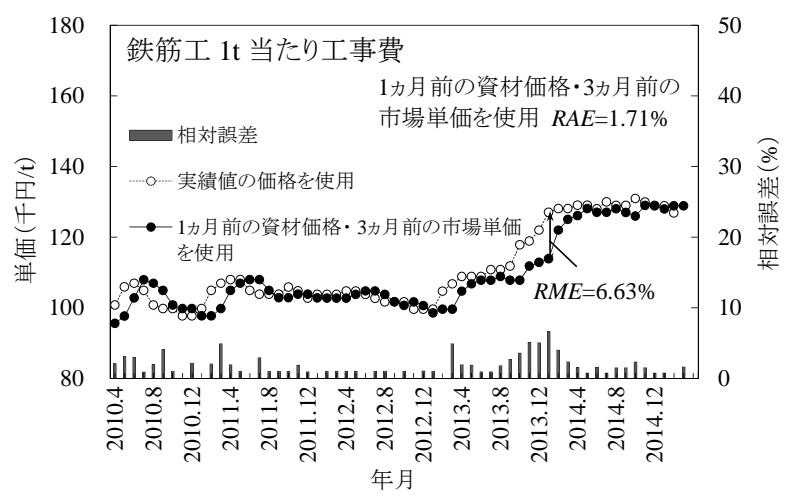

図-13 1 カ月前の資材価格・3 カ月前の市場単価により 算出した工事費の誤差

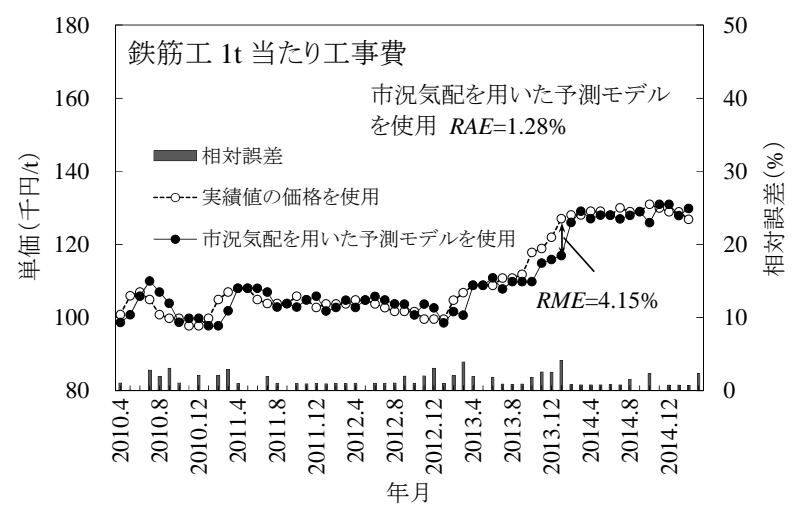

図-14 実績值と市況気配を用いた予測モデルにより 算出した工事費の誤差

算した例では，鉄筋工事費は，1カ月前の資材価格・3力 月前の市場単価を使用して算出した工事費と比較して実 績值との差を4,000円/t縮小寸ることが示された.

図-12は，実績值を使用して算出した鉄筋工事費と1カ 月前の資材価格・3力月前の市場単価を使用して算出し た鉄筋工事費および市況気配を用いた予測モデルを使用 して算出した鉄筋工事費との価格差を示したものである. 対象期間は，2010年4月から2015年3月の5年間であり， 格差は絶対值で示している. この図より実績值との価格 差は，市況気配を用いた予測モデルを使用して算出した 場合の方が1か月前の資材価格・3カ月前の市場単価を使 用して算出した場合の価格差より縮小したデータ数（月 数）が多くなっている事が分かる．特に，価格差が大き い5,000円/t以上の階層において価格差の抑制効果が顕著 に表れている.

\section{（3）実績值との平均相対誤差による検証}

図-13には，2010年4月から2015年3月（5年間）の期間 における実績值と1カ月前の資材価格および3力月前の市 場単価の值を使用して算出した鉄筋工事費（1t当たりの 工事費) の価格誤差を示したものである.また，図-14 は，前述した同期間における実績值と市況気配を用いた 予測モデルを使用して算出した価格の值を使用して算 出した鉄筋工事費の価格誤差を示したものである.

この分析期間における実績值との平均相対誤差は， 1 力月前の資材価格・3力月前の市場単価を使用して算出 した鉄筋工事費で1.71\%（最大相対誤差6.63\%），市況気 配を用いた予測モデルを使用して算出した鉄筋工事費で 1.28\%（最大相対誤差 $4.15 \%$ ）であり，鉄筋工事費による 比較検証においても推定精度は改善されるという結果が 得られた。

\section{7. おわりに}

本研究では, タイムラグの影響による発注者側が用い る価格データと実勢価格との乘離を抑制させることや， 応札者における取引先等の実勢価格の妥当性の評価など に役立てるため, 定量的な分析を行い物価変動によるリ スクに対応した客観的かつ精度の高い資材価格等の予測 モデルの構築を行った.

はじめに分析の対象とした資材価格は，公共工事にお ける使用量のシュアが大きく, 主要資材の中でも価格の 変動が著しかった異形棒鋼（SD295A D16 東京地区 大 口）を対象とした．市況気配を用いた予測モデルの説明 変数には, 過去の価格情報から得られる「今月の価格 (実績值)」と過去からの資材価格の動きである「変動 率（今月/前月）」，そして，今月から先に向けて価格 がどのように動くかという未来の情報である「市況気 配」を適用して重回帰モデルによる資材価格の予測モデ ル構築を試みた。

予測における推定精度は, 予測值の実績值に対する相 対誤差の分析期間中の平均相対誤差により評価した. そ の結果，資材価格の予測モデルを使用した場合の同定期 間における平均相対誤差は1.69\%であり，比較対象とし た1力月前の資材価格を使用した場合の資材価格で平均 相対誤差 $2.06 \%$ よ精度の高いモデル構築が得られた。 検証期間における予測值と実績值の平均相対誤差は資材 価格の急激な変動期を除けば1.51\%であり高い推定精度 が得られた。

次に資材価格の分析で行った手法を，市場単価の予測 にも適用して市場単価の予測モデルを構築した. 分析結 果は，資材価格の予測モデルと同様に精度の高いモデル を得る事が出来た．さらに工事費による検証では, 1力 
月前の資材価格・3カ月前の市場単価を使用して試算し た結果よりも，市況気配を用いた予測モデルを使用して 算出した予測価格の方が実績值との乘離が小さくなると いう効果が確認された.

予測モデルにおいては, 各説明変数が予測価格に与え る影響の強さについて標準化偏回帰係数を指標として分 析を行った. その結果として, 今月の価格の影響が大き いことが確認されたが，説明変数に市況気配を適用する ことで，より精度の高い価格予測が可能となった．一方 で価格の大幅な高騰（下落）が発生した時には，実績值 との誤差が大きくなる結果となった。 これは, 分析期間 中における予想モデルのパラメータが一定值で固定され ており，同定期間中にはなかったような，例えば新興国 の需要の急騰やリーマンショックなどの出来事が考慮さ れていないことが大きな原因と考えられる. それらの出 来事に起因する要素をモデルに組み込むことが出来れば 予測精度は向上するが，それは今後の課題として残され ている.

以上のように，「市況気配」を適用した資材価格の予 測モデルは資材価格, 市場価格, 工事費の予測手法とし て有効であることが示されたといえる.

本研究の成果は, 不調・不落の一因と考えられる積算 額の乘離抑制に期待できるが，それのみならず，設計変 更時にはスライド条項の適用時も含めて今後の価格動向 を見据えて変更を行うなど，リスクマネジメントや実行 予算におけるコストマネジメント等にも適用範囲を拡大 することが可能と考える.

なお，今回対象とした異形棒鋼以外の他の主要建設資 材に関しても「市況気配」を適用寸るという概念を適用
して価格予測モデルを構築することにより，より市場動 向に即した予定価格の設定に寄与できるものと考える.

謝辞 : 本研究にあたつては, 東洋大学理工学部都市環境 デザイン学科鈴木信行研究室により多大なご支援を頂い た.ここに深く感謝申し上げます.

\section{参考文献}

1）佐藤直良, 木下誠也, 松本直也, 芦田義則, 大場敦 史：不調・不落の発生原因に関寸る分析, 土木学会 論文集 F4 Vol.66，pp.205-218，2010。

2) 塩井直彦: 不調不落の発生状況とその対策, 建設マ ネジメント技術，pp.7-10，2008年 12 月号.

3）国土交通省公共工事の品質確保の促進に関寸る関係 省庁連絡会議: 発注関係事務の運用に関する指針, 平成 27 年 1 月 30 日.

4) 鈴木信行, 村田裕介, 加藤佳孝：非対称情報下にお ける価格設定 (調達) に関寸る一考察, 土木学会年 次学術講演会講演概要集 Vol.67 巻, pp. VI903-904, 2012 年.

5）建設物価調查会 : 建設物価, 2005 年 4 月号 2015 年 4 月号.

6) 宮本和明：建設資材価格変動リスク分析のための時 系列分析, 建設物価調查会 総研レポートVol.5, pp.29-37, 2011.4.

7) 水野明哲, 飯田明由, 春口卓也: Wavelet 解析による 改良グランビルの法則に基づく株価予測，第 33 回可 視化情報シンポジウム講演論文集, pp.49-52, 2005.

8）建設物価調査会：土木コスト情報，2005 年 4 月号〜 2015年 4 月号.

(2015.5.18 受付)

\title{
A STUDY ON THE CONSTRUCTION MATERIAL PRICES PREDICTION METHOD UTILISING THE DEVIATION RATE OF THE MOVING AVERAGE
}

\author{
Yusuke Murata, Masahiro Arimori and Nobuyuki Suzuki
}

Understanding and efficiently estimating construction material prices is fundamental to the cost formation of an effective budget for public works. Early inefficiencies in evaluation can quickly develop to impact project risk and significantly impact on project programme and procurement management processes throughout the subsequent construction period. The market prices of materials are subject to regular surveys which give useful benchmark data, however there are time-lags in the production and release of survey data and impacts of unforeseen international (e.g. oil price fluctuations) or local events which can cause significant deviations from tender or budget forecasts and expectations.

In this paper, we evaluate actual construction material price data accumulated over the last five years, and examine the deviation of the moving average as a potential modelling tool for the prediction of prices within the near future. We validate the model within a relative average error using a multiple regression technique where price prediction is a purpose function that accounts for the current price, market tendency, and the deviation of the moving average. Finally we consider and discuss the likely effectiveness of our proposed price prediction model in reducing the likelihood of tender failures and other impacts on public works projects. 